\title{
Peningkatan Hasil Belajar Matematika Siswa Sekolah Dasar Melalui Pembelajaran Berbasis Penilaian
}

\author{
Putri Anggoro Kasih, Yoppy Wahyu Purnomo \\ Program Studi PGSD, Universitas Mubammadiyah Prof. DR. HAMKA \\ Korespondensi:yoppy.w.purnomo@uhamka.ac.id
}

\begin{abstract}
Abstrak. Penelitian ini bertujuan untuk mengetabui apakah terdapat peningkatan hasil belajar matematika siswa melalui pembelajaran berbasis penilaian. Penelitian ini menggunakan metode preeksperimental dengan desain pre-test dan post-test dalam satu kelompok. Partisipan dalam penelitian ini adalah 40 siswa kelas 5 di salah satu Sekolah Dasar di Kota Depok tabun ajaran 2014/2015. Pengumpulan data dilakukan menggunakan pre-test dan post-test. Kedua instrumen tersebut diujicoba terlebih dabulu sebelum diberikan pada partisipan. Analisis data dilakukan dengan menggunakan uji $t$ dengan taraf signifikansi $5 \%$. Temuan yang diperoleh dalam penelitian ini adalah terdapat peningkatan hasil belajar matematika siswa yang ditunjukkan dengan nilai $t_{\text {hitung }}=15,73>1,684=t_{\text {kritis }}$. Penelitian ini mengisyaratkan bahwa penilaian dalam proses pembelajaran matematika tidak hanya digunakan sebagai bentuk pertanggungjawaban dalam proses belajar-mengajar, namun juga dapat dijadikan sarana untuk mendukung belajar-mengajar. Penelitian selanjutnya dapat mengeksplorasi lebih jauh beberapa strategi lain dalam ABL sebingga semakin memperkaya metode (dan alternatif) untuk diterapkan di kelas.
\end{abstract}

Kata kunci: pembelajaran berbasis penilaian, hasil belajar, pembelajaran matematika, sekolab dasar

\begin{abstract}
This study aims to find out whether there is an increase in students' mathematics learning outcomes through the implementation of assessment-based learning. This study employed pre-experimental method with one-group pretest-posttest design. The participants were 40 students in $5^{\text {th }}$ grade in one of the elementary school in Depok in the 2014/2015 academic year. The data were collected from pre-test and post-test. The instruments were tested before it was given to the participants. The data analysis was performed using the t-test with significance level of 5\%. The result indicated that there is significantly increase in the student mathematics achievement that can be shown by $t_{\text {obs }}=15.73>1.684=t_{\text {tab }}$. This study suggests that assessment in mathematics learning process is not only used as a form of accountability in the teaching-learning process, but also as a means to support teaching and learning. Further research can explore in more depth some of other strategies in the ABL and the more enriching methods (and alternatives) to be applied in the classroom.
\end{abstract}

Keywords: Assessment-based learning, achievement, mathematics learning, elementary school 


\section{Pendahuluan}

Istilah "penilaian" dalam proses pembelajaran menjadi sebuah perdebatan yang menarik untuk dikaji (Purnomo, 2014, 2015; Wolf, Bixby, Glenn III, \& Gardner, 1991). Di satu sisi, penilaian diartikan sebagai sebuah cara untuk mengidentifikasi sejumlah pengetahuan yang "disimpan" dalam pikiran peserta didik. Di sisi lain, penilaian diartikan sebagai sebuah cara untuk menyediakan informasi atau umpan balik (feedback) baik kepada guru maupun peserta didik untuk memandu cara mengajar dan belajar untuk mencapai tujuan bersama.

Paradigma penilaian sebagai sebuah cara untuk mengidentifikasi pengetahuan identik dengan praktik-praktik pengujian beresiko tinggi (bigh-stake testing) yang diiringi dengan pemberian skor, grading, dan/atau membandingkan performa siswa dengan standar eksternal baku sebagai bentuk akuntabilitas. Di Indonesia, budaya pengujian lebih mendominasi dalam sistem pendidikan. Hal ini dapat diverifikasi dari kebijakan pendidikan yang terfokus pada hasil ujian nasional, ujian (mid) semester, dan ujian-ujian beresiko tinggi di sekolah sebagai kriteria sukses dalam proses pendidikan.

Purnomo (2015, p. 183) mengajukan beberapa pertanyaan sebagai kritik terhadap praktik-praktik pada budaya pengujian, di antaranya "apakah proses penilaian hanya dipandang sebagai sebuah pertanggungjawaban atas apa yang telah dilakukan oleh guru dan siswa di kelas? Apakah pengajaran yang dilakukan hanya untuk diujikan (teaching to test)? Apakah penilaian (melalui pengujian) yang dilakukan telah merefleksikan hasil pembelajaran secara keseluruhan?” Ketidakrelevanan budaya pengujian dalam praktikpraktik penilaian terhadap proses belajar-mengajar diantaranya adalah: 1) memisahkan penilaian dalam proses pembelajaran, 2) mendorong pembelajaran secara hafalan dan superfisial, 3) tujuan utama penilaian lebih dipandang sebagai kompetisi, 4) membandingkan antara siswa satu dengan yang lain ketimbang perbaikan personal, 5) tidak memperhatikan kesulitan belajar yang mungkin dialami siswa, 6) menjadi pendorong pada kecemasan berlebih, 7) berpengaruh pada rendahnya self-esteem dan selfbeliefs sebagai pebelajar, dan 8) mendorong siswa untuk mendevaluasikan proses belajar dan penilaian itu sendiri (Purnomo, 2014, 2015)

Mengacu apa yang diungkap beberapa peneliti, penilaian tidak hanya dipandang sebagai sebuah pertanggungjawaban dalam proses belajar-mengajar, namun juga dapat dijadikan sarana untuk mendukung belajar-mengajar (Black \& Wiliam, 2010; Purnomo, 2014, 2015). Istilah mendukung belajar-mengajar di sini dapat diartikan sebagai sebuah proses untuk menciptakan umpan balik baik bagi siswa tentang belajarnya dan bagi guru tentang mengajarnya. Terkait dengan pembelajaran matematika, beberapa peneliti menemukan bahwa praktik penilaian yang terintegrasi dalam proses belajar-mengajar memberikan dampak yang signifikan terhadap peningkatan hasil belajar matematis siswa (Balan, 2010; Purnomo, 2015).

Berdasarkan data empiris di atas, penelitian ini ingin mengonfirmasi dengan melihat peran penilaian sebagai bagian yang tak terpisahkan dalam mendukung proses belajarmengajar matematika. Istilah pembelajaran berbasis penilaian diadopsi dari penelitian sebelumnya (Purnomo, 2014, 2015) dan diberikan pada siswa sekolah dasar untuk melihat peningkatan hasil belajar matematika. Peningkatan dalam konteks ini adalah kecenderungan positif dari perubahan hasil belajar kognitif siswa sebelum dan sesesudah dikenai perlakuan.

Praktik penilaian (termasuk tes), pengukuran, dan evaluasi yang memungkinkan terjadi dalam satu proses pembelajaran sering kali menyebabkan miskonsepsi (Miller, Linn, \& Gronlund, 2012; Purnomo, 2014). Sebagian besar dalam praktiknya di lapangan, penilaian lebih sering dipersepsikan sama dengan melakukan tes untuk mengukur dan mengevaluasi kinerja peserta didik (Miller et al., 2012). Meskipun tes merupakan salah 
satu alat atau metode untuk melakukan penilaian, namun penilaian tidak hanya dapat dilakukan melalui penggunaan tes.

Brookhart (2005) mendeskripsikan penilaian, pengukuran, dan evaluasi dengan contoh penerapan seperti berikut: Guru memberikan ujian tengah semester dan nilai peserta didik mencapai 64 persen, maka guru tersebut melakukan penilaian sekaligus pengukuran. Jika guru menggunakan informasi tersebut untuk menyimpulkan bahwa peserta-didiknya harus mendapatkan bantuan tambahan atau perbaikan tugas, maka guru melakukan evaluasi. Jika guru bertanya tentang masalah yang mungkin terjadi pada peserta didik, respon peserta didik merupakan informasi penilaian tetapi bukan pengukuran (tidak ada skala numerik). Keputusan guru tentang tingkat wawasan peserta didik adalah evaluasi, sehingga proses evaluasi dilakukan setelah melalui proses penilaian.

Dalam literatur berbeda, Miller et al. (2012) membedakan terminologi penilaian, pengukuran, dan tes dengan sebuah jawaban dari pertanyaan-pertanyaan. Penilaian menjawab pertanyaan: "seberapa baik individu bekerja?", pengukuran menjawab pertanyaan "berapa banyak?", dan tes menjawab pertanyaan: "seberapa baik individu bekerja (baik dibandingkan dengan orang lain atau dibandingkan dengan domain performa tugas?"). Secara ringkas, penilaian digunakan untuk memperoleh informasi kuantitatif (melalui tes dengan cara melakukan pengukuran) dan informasi kualitatif (pertanyaan, dialog kelas, observasi, dan feedback) yang selanjutnya digunakan untuk evaluasi (menentukan dan membuat pertimbangan atau keputusan tentang nilai).

Berdasarkan uraian di atas, penilaian dapat diartikan sebagai serangkaian aktivitas untuk memperoleh informasi kualitatif dan kuantitatif ketika awal, sedang berlangsungnya proses, maupun di akhir pembelajaran untuk tujuan tertentu (Brookhart, 2004; Purnomo, 2014). Tes merupakan bagian dari tipe penilaian yang umumnya berisikan sekumpulan pertanyaan yang diberikan pada periode waktu tertentu untuk individu atau semua peserta didik (Miller et al., 2012; Purnomo, 2014). Pengukuran berarti menerapkan seperangkat aturan atau menetapkan sejumlah deskripsi numerik dari hasil tes atau tipe lain dari penilaian untuk mendapatkan informasi kuantitatif tentang hal tersebut (Brookhart, 2004; Hargreaves, 2005; Miller et al., 2012; Webb, 1992). Evaluasi berarti menggunakan informasi dari penilaian untuk membuat pertimbangan (keputusan) tentang nilai dari sesuatu (Brookhart, 2004; Purnomo, 2014; Webb, 1992).

Selanjutnya, istilah pembelajaran berbasis penilaian (assessment-based learning, disingkat $\mathrm{ABL}$ ) digunakan untuk mewadahi tiga bentuk tujuan penilaian, yakni penilaian sebagai pembelajaran (assessment as learning, disingkat $\mathrm{A} a \mathrm{~L}$ ), penilaian untuk pembelajaran (assessment for learning, disingkat $\mathrm{A} f \mathrm{~L}$ ), penilaian pada pembelajaran (assessment of learning, disingkat AoL). Dengan kata lain, ABL adalah sebuah proses mengumpulkan bukti belajar baik secara kualitatif maupun kuantitatif sebagai bentuk umpan balik kepada siswa tentang belajarnya dan sebagai umpan balik kepada guru tentang mengajarnya untuk berkolaborasi menggapai tujuan bersama.

Fokus utama ABL adalah bagaimana mendesain pembelajaran berdasarkan informasi dari penilaian yang melibatkan siswa dan guru di dalamnya. Sebagaimana fokus tersebut, komposisi di antara tiga bentuk penilaian di atas (yakni AsL, AfL, dan AoL), pembelajaran berbasis penilaian lebih menekankan pada proses bagaimana penilaian digunakan sebagai pembelajaran.

Setidaknya terdapat empat karakeristik utama yang harus diperhatikan dalam pelaksanaan pembelajaran berbasis penilaian sehingga dapat berjalan efektif, yakni fokus pada belajar, pertanyaan efektif, umpan balik formatif, serta penilaian diri dan sejawat (Lee, 2006; Purnomo, 2015). Masing-masing poin tersebut dapat dijabarkan sebagai berikut. 
Fokus pada belajar

Fokus pada belajar mencakup dua elemen penting, yakni tujuan pembelajaran dan kriteria sukses (Lee, 2006; Purnomo, 2015; CCEA, 2009). Lebih lanjut, Lee (2006) berpendapat bahwa menetapkan tujuan pembelajaran mengandung makna bahwa siswa akan memahami apa yang mereka pelajari dan dapat menilai kemajuannya dalam belajar. Sedangkan, kriteria sukses memberitahu siswa tentang apa saja yang harus mendapatkan perhatian lebih pada kegiatan mereka dalam rangka untuk mendapatkan tujuan pembelajaran yang diinginkan.

Beberapa peneliti merekomendasikan beberapa strategi yang dapat diterapkan untuk menjaga fokus belajar (Kusdiwelirawan \& Purnomo, 2014; Lee, 2006; Purnomo, 2015), di antaranya: 1) mengidentifikasi, merencanakan, dan memahami tujuan dan kriteria sukses, 2) membuat daftar tujuan belajar dan/atau mind map dengan bahasa anak, singkat, dengan ukuran yang besar dan menarik, jika perlu disertai gambar visual melalui poster, sedangkan kriteria sukses disesuaikan dengan tujuan pembelajaran dan mencakup pembelajaran yang akan dilakukan secara spesifik. Langkah kedua ini juga dapat dilakukan dengan menampilkan tujuan dan kriteria sukses di layar proyektor selama pembelajaran atau menuliskannya di papan tulis dan tidak menghapusnya selama pembelajaran, 3) memberikan/menyampaikan alasan belajar, 4) menginformasikan dan mendiskusikan kepada peserta didik tentang fokus belajar, dan 5) melakukan peninjauan ulang tujuan belajar selama kegiatan pembelajaran.

\section{$\underline{\text { Pertanyaan efektif }}$}

Pertanyaan adalah sembarang bentuk kalimat interogatif baik verbal dan nonverbal untuk mengkomunikasikan materi kepada seseorang untuk tujuan-tujuan tertentu (Wilen, 1987). Terdapat beberapa strategi yang dapat digunakan untuk mengembangkan pertanyaan efektif, diantaranya: 1) memaksimalkan pertanyaan terbuka, salah satunya dengan mengeksplorasi pertanyaan dengan teknik probing dan menciptakan respon lanjutan berupa pertanyaan lebih lanjut segera (Black, Harrison, Lee, Marshall, \& Wiliam, 2003, 2004; Lee, 2006; Purnomo, 2015; Redhana, 2014), 2) mengeksplorasi respon terutama contoh jawaban yang salah dan miskonsepsi umum untuk sumber diskusi kelas (Lee, 2006; Purnomo, 2015), 3) menyediakan waktu untuk berpikir (waiting time) (Black et al., 2003, 2004; Rowe, 1986, 1987), dan 4) menggunakan strategi “no hands up" kecuali untuk memberikan kesempatan siswa untuk mengajukan pertanyaan atau beragumen (Black et al., 2003, 2004; Lee, 2006; Purnomo, 2015).

\section{Umpan balik}

Umpan balik dapat diartikan sebagai informasi yang diberikan tentang kesuksesan kinerja atau pemahaman seseorang yang terlibat didalamnya berdasarkan kriteria tertentu. Umpan balik dapat mendukung pembelajaran jika meliputi tiga aspek yang perlu diketahui oleh agen yang terlibat yakni ke mana akan melangkah? Sejauh mana posisinya terhadap tujuan yang akan dicapai? Bagaimana saya akan melangkah selanjutnya? (Hattie \& Timperley, 2007; Sadler, 1989). Umpan balik dalam ABL dapat tercipta dengan memaksimalkan tiga unsur yang lain.

\section{Penilaian diri dan sejawat}

Penilaian diri merupakan proses yang melibatkan peserta didik dalam memantau, mengidentifikasi, membuat dan mengambil keputusan mereka sendiri tentang belajarnya (McMillan \& Hearn, 2008). Lebih lanjut, McMillan \& Hearn berpendapat bahwa penilaian diri adalah kombinasi dari tiga komponen yang terkait dalam siklus atau proses yang berkelanjutan dalam pembelajaran, yaitu memonitor diri, menimbang diri, dan 
menentukan tujuan belajar selanjutnya. Di sisi lain, penilaian sejawat adalah proses review, klarifikasi, dan koreksi yang dilakukan oleh peserta didik terhadap peserta didik lainnya maupun sebaliknya berdasarkan kriteria tertentu yang dapat berupa umpan balik dan/atau nilai (Falchikov, 2007; Kim, 2009). Secara praktis, penilaian sejawat merupakan proses yang melengkapi dan dalam situasi tertentu menjadi prasyarat untuk penilaian diri (Black et al., 2003, 2004). Beberapa teknik dan strategi untuk menyediakan proses penilaian diri dan sejawat di kelas dapat dilakukan dengan menggunakan rubrik, presentasi lisan, dan peer feedback.

\section{Metode Penelitian}

Penelitian ini menggunakan metode pre-eksperimental dengan desain tes sebanyak dua kali, yaitu pre-test yang dilakukan sebelum perlakuan dan post-test yang dilakukan setelah perlakuan. Partisipan dalam penelitian ini adalah 40 siswa kelas 5 di salah satu Sekolah Dasar di Kota Depok pada semester genap tahun ajaran 2014/2015. Prosedur penelitian ini dimulai dengan menyusun instrumen tes hasil belajar matematika yang dibatasi pada bahasan bangun datar. Instrumen yang disusun dikonsultasikan pada dua pakar pendidikan matematika untuk melihat kesesuaian antara item dengan indikator yang ada. Untuk melihat keterbacaan soal, dua siswa sekolah dasar diminta untuk mengerjakan soal dan langsung didiskusikan dengan peneliti. Berdasarkan tahapan tersebut, beberapa revisi pertanyaan dilakukan dengan mengacu saran-saran pakar dan tanggapan siswa. Selanjutnya, instrumen diberikan pada siswa sekolah dasar untuk melihat tingkat reliabilitas. Indeks reliabilitas intrumen diperoleh sebesar 0,85 > 0,7 yang berarti instrumen memiliki reliabilitas yang memadai.

Penerapan ABL mengacu pada unsur-unsur dan strategi-strategi yang dikembangkan oleh Purnomo (2015), yaitu fokus pada belajar, pertanyaan efektif, umpan balik, dan penilaian diri dan sejawat. Analisis data pada penelitian ini dilakukan dengan uji-t yang sebelumnya dilakukan uji analisis prasyarat, yakni normalitas. Hipotesis yang diuji dalam penelitian ini adalah sebagai berikut :

$H_{a}$ : Terdapat peningkatan hasil belajar matematika siswa yang dikenai pembelajaran berbasis penilaian.

$H_{o}$ : Tidak terdapat peningkatan hasil belajar matematika siswa yang dikenai pembelajaran berbasis penilaian.

\section{Hasil Penelitian dan Pembahasan}

Eksperimentasi pembelajaran berbasis penilaian dalam penelitian ini mengadaptasi apa yang telah dikembangkan oleh Purnomo (2015). Berikut beberapa strategi dalam pembelajaran berbasis penilaian.

\section{Tabel 1. Desain Pembelajaran Berbasis Penilaian}

Unsur $\mathrm{A} B \mathrm{~L}$

- Guru merencanakan tujuan dan kriteria sukses berdasarkan kompetensi dasar yang akan dicapai.

- Disampaikan kepada siswa di awal pembelajaran dan

Fokus

Pembelajaran ditampilkan dalam bentuk poster yang ditempel di sekeliling kelas.

- Kriteria sukses dinegosiasikan dengan siswa dengan mengacu pada poin atau catatan-catatan yang perlu dikembangkan. 
Unsur $A B L$

Pertanyaan Efektif

Umpan Balik Formatif

Penilaian diri dan Sejawat
Praktik ABL

- Mengeksplorasi pertanyaan berupa fakta dengan teknik probing questions dan menciptakan respon lanjutan berupa pertanyaan lebih lanjut segera sehingga bukan hanya untuk memberikan klarifikasi.

- Mengeksplorasi respon siswa terutama contoh jawaban yang salah dan miskonsepsi umum untuk sumber diskusi kelas.

- Memberikan waktu berpikir pada dua periode penting, yaitu waiting time 1 dan waiting time 2 serta melatih keterampilan "waktu berpikir" kepada anak dalam merespon pertanyaan. Waiting time 1, yakni interval antara berakhirnya pertanyaan guru dan dimulai dari respon siswa, sedangkan waiting time 2 merupakan akumulasi jeda antara jawaban/argumen siswa sebelum guru atau siswa lain melakukan elaborasi atau penjelasan lebih lanjut.

- Menggunakan strategi "no bands up" kecuali untuk memberikan kesempatan siswa untuk mengajukan pertanyaan.

- Menggunakan permasalahan matematika yang terkait dengan konteks dan pengalaman siswa.

- Memberikan komentar lisan konstruktif dari respon atau jawaban siswa.

- Memberi komentar tertulis konstruktif dan mengembalikan hasil pekerjaan siswa dalam rentang waktu sesegera mungkin.

- Guru menggunakan jurnal dan atau rubrik untuk memantau poin-poin penting dalam aktivitas pembelajaran dan sesering mungkin didiskusikan dengan siswa dan orang tua.

- Umpan balik ditekankan pada perbaikan selanjutnya (feed forward) bukan hanya menilai kinerja, yakni mengambil poin penting untuk refleksi diri dan diskusi kelas.

- Menyediakan kesempatan kepada siswa untuk mengomentari respon atas jawaban dan pertanyaan siswa lain di kelas. Hal ini dapat dilakukan dengan kegiatan presentasi lisan oleh siswa.

- Guru melakukan verifikasi keyakinan diri siswa dalam belajar dengan menggunakan beberapa teknik di antaranya "thumbs up" atau "traffic light".

- Menyediakan proses umpan balik sejawat terhadap pekerjaan atau lembar kerja anonim dari siswa lain.

- Menyediakan variasi untuk respon sejawat, seperti menukar teman sejawat.

- Siswa menggunakan mini-rubrik untuk mereka bandingkan dengan tujuan dan kriteria sukses. 
Skor hasil pre-test dan post-test dianalisis secara deskriptif untuk melihat skor rata-rata dan deviasi standar. Berdasarkan hasil analisis diperoleh rerata kelompok eksperimen sebesar 55 dengan deviasi standar 13,12 dan rerata kelompok kontrol sebesar 67,73 dengan deviasi standar 13,82. Hasil ini dapat dirangkum pada Tabel 2 berikut.

Tabel 2. Deskripsi Skor Pre-test dan Post-test

\begin{tabular}{llcc}
\hline & $\mathrm{N}$ & Mean & Std. Deviasi \\
\hline Pre-test & 40 & 55 & 13,12 \\
Post-test & 40 & 67,73 & 13,82 \\
\hline
\end{tabular}

Berdasarkan data deskriptif pada Tabel 1, rerata kelompok eksperimen lebih tinggi daripada rerata kelompok kontrol. Untuk menguji apakah peningkatannya signifikan, maka perlu dilakukan uji-t. Uji $t$ mensyaratkan bahwa kedua data di atas harus berdistribusi normal. Uji normalitas dilakukan dengan menggunakan uji Chi Kuadrat yang menghasilkan $\chi_{h}^{2}=3,85<11,07=\chi_{t}^{2}$ untuk data pre-test dan $\chi_{h}^{2}=9,77<11,07=\chi_{t}^{2}$ untuk data post-test. Dengan demikian, kedua data tersebut berdistribusi normal.

Tabel 3. Hasil Uji Normalitas

\begin{tabular}{ccccccl}
\hline Kelompok & $\alpha$ & $\mathrm{N}$ & $\chi_{\boldsymbol{h}}^{2}$ & $\chi_{\boldsymbol{t}}^{2}$ & Kriteria & Kesimpulan \\
\hline Pre-test & 0,05 & 40 & 3,85 & \multirow{2}{*}{11,07} & $\chi_{h}^{2}<\chi_{t}^{2}$ & Distribusi Normal \\
Post-test & 0,05 & 40 & 9,77 & & \\
\hline
\end{tabular}

Hasil uji $t$ dari data pre-test dan post-test menunjukkan bahwa $t_{\text {hitung }}=15,73>$ $1,684=t_{\text {tabel }}$. Dengan demikian, dapat disimpulkan bahwa terdapat peningkatan yang signifikan antara pre-test dan post-test. Rangkuman dari uji hipotesis ini ditunjukkan oleh Tabel 4.

Tabel 4. Hasil Hipotesis Uji-t

\begin{tabular}{ccrccl}
\hline Kelompok & $\mathrm{N}$ & $\overline{\boldsymbol{x}}$ & $\boldsymbol{t}_{\text {hitung }}$ & $\boldsymbol{t}_{\text {tabel }}$ & Kesimpulan \\
\hline Pretest & 40 & 54,88 & & & Peningkatan \\
Postetest & 40 & 68,10 & 15,73 & 1,684 & yang \\
& & & & & sifnifikan \\
\hline
\end{tabular}

Temuan penelitian ini sejalan dengan beberapa penelitian sebelumnya (Balan, 2010; Purnomo, 2015; Wiliam, Lee, Harrison, \& Black, 2004) yang sama-sama menyatakan bahwa penilaian yang terintegrasi dalam pembelajaran selain digunakan sebagai cara untuk menyediakan umpan balik, dapat digunakan sebagai sebuah pendekatan yang jitu untuk mendukung pembelajaran matematika. Merujuk temuan Balan (2010), siswa yang dikenai perlakuan ini lebih mampu menginterpretasikan masalah dan menggunakan metode matematika yang tepat untuk menyelesaikannya. Siswa juga menunjukkan perbaikan terkait alasan dari solusi matematika mereka, bagaimana menyajikan solusi dengan cara yang jelas, dan cara tepat menggunakan simbol, terminologi, dan kaidah matematik.

Peneliti meminimalisir pertanyaan kelas dan menggunakan pertanyaan-pertanyaan terbuka dengan teknik probing untuk merangsang berpikir kritis dan menggali lebih mendalam apa yang diketahui siswa. Hal ini juga sejalan dengan temuan Purnomo (2015) 
yang menyatakan bahwa pertanyaan terbuka dalam ABL menuntun siswa untuk berpikir kritis, merangsang imajinasi dan kreativitas, dan pada gilirannya mengantarkan siswa untuk lebih mampu menginterpretasikan dan menyelesaian masalah matematis. Dengan kata lain, siswa yang terbiasa dengan ABL juga terbiasa sebagai problem solver.

Umpan balik, penilaian diri dan sejawat dalam ABL juga berperan dalam menuntun siswa untuk terbiasa merefleksikan apa yang dilakukan, apa yang akan dilakukan, dan apa yang telah dilakukan. Umpan balik ke siswa bukan berupa skor atau nilai atau tanda benar atau salah, namun lebih kepada komentar-komentar konstruktif seperti yang diilustrasikan pada Gambar 1 berikut. Strategi ini menyediakan kesempatan bagi siswa dan orang tuanya untuk mengevaluasi apa yang telah dikerjakan dan bagaimana seharusnya.

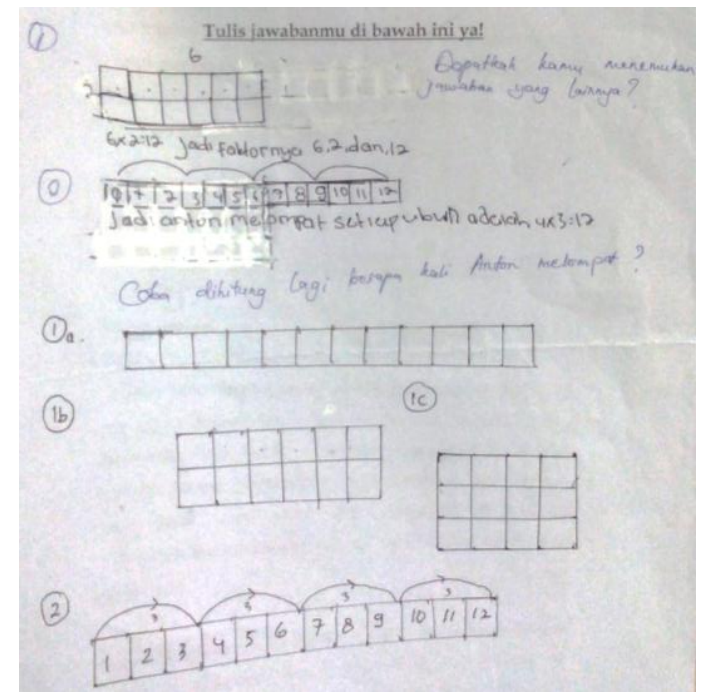

\section{Gambar 1. Contoh umpan balik terhadap pekerjaan siswa}

Peneliti juga menggunakan presentasi lisan untuk menyediakan umpan balik, penilaian diri dan sejawat. Presentasi lisan merupakan bentuk penilaian yang memungkinkan terjadinya penilaian diri ketika siswa atau kelompok siswa mendapatkan umpan balik dari apa yang mereka sampaikan di kelas, dan memungkinkan terjadinya penilaian sejawat ketika tanggapan atau respon terjadi ketika presentasi perlu klarifikasi dan diskusi. Hal ini sebagaimana yang diungkap oleh beberapa peneliti (Hristova, 2014; Lianghuo \& Mei, 2007; Ma, Millman, \& Wells, 2008) bahwa presentasi lisan merupakan salah satu metode penilaian yang menyediakan aktivitas penilaian diri dan sejawat, untuk mengkomunikasikan ide dan mengklarifikasi pemahaman secara lisan. Penilaian sejawat dalam kegiatan presentasi lisan terjadi ketika siswa memberikan argumen terhadap jawaban atau penjelasan siswa, sedangkan penilaian diri terjadi ketika komentar dari teman menjadi sebuah kritik diri atau refleksi diri untuk mengklarifikasi jawaban semula.

\section{Simpulan}

Hasil penelitian ini menemukan adanya peningkatan hasil belajar matematika setelah dilakukan ABL. Hal ini dapat menjadi sebuah pertimbangan bagi praktisi dan pembuat kebijakan untuk mengubah paradigma budaya pengujian menjadi budaya penilaian. Budaya penilaian lebih ditujukan pada bagaimana penilaian digunakan sebagai bentuk umpan balik korektif yang mendukung proses belajar dan mengajar di kelas matematika. Dengan kata lain, bentuk-bentuk pertanggungjawaban dari proses penilaian dapat dipandang dari segi proses maupun hasil. Berbeda dengan budaya pengujian yang 
lebih berorientasi pada hasil tanpa memandang proses. Lebih lanjut, penelitian selanjutnya dapat mengeksplorasi lebih jauh beberapa strategi lain dalam ABL sehingga semakin memperkaya metode (dan alternatif) untuk diterapkan di kelas.

\section{Daftar Pustaka}

Balan, A. (2010). Assessment for learning: A case study in mathematics education. (Doctoral thesis), Malmö University, Holmbergs, Malmö. Retrieved from www.mah.se/muep (Malmö Studies in Educational Sciences No. 68)

Black, P., Harrison, C., Lee, C., Marshall, B., \& Wiliam, D. (2003). Assessment for learning: Putting it into practice. Maidenhead, U.K.: Open university Press.

Black, P., Harrison, C., Lee, C., Marshall, B., \& Wiliam, D. (2004). Working inside the black box: Assessment for learning in the classroom. Phi Delta Kappan, 86(1), 921.

Black, P., \& Wiliam, D. (2010). Inside the Black Box: Raising Standards through Classroom Assessment. Phi Delta Kappan, 92(1), 81-90. doi: 10.1177/003172171009200119

Brookhart, S. M. (2004). Assessment theory for college classrooms. New Directions for Teaching and Learning, 100, 5-14.

Falchikov, N. (2007). The place of peers in learning and assessment. In D. Boud \& N. Falchikov (Eds.), Rethinking assessment in higher education: Learning for the longer term (pp. 128-143). London: Routledge.

Hargreaves, E. (2005). Assessment for learning? Thinking outside the (black) box. Cambridge Journal of Education, 35(2), 213-224.

Hattie, J., \& Timperley, H. (2007). The power of feedback. Review of educational research, $77(1), 81-112$.

Hristova, Z. (2014). Using Peers to Assess Oral Presentations to Foster Learning. International Journal of Innovation in Science and Mathematics Education, 22(3), 74-80.

Kim, M. (2009). The impact of an elaborated assessee's role in peer assessment. Assessment \& Evaluation in Higher Education, 34(1), 105-114. doi: 10.1080/02602930801955960

Kusdiwelirawan, A., \& Purnomo, Y. W. (2014). Mendesain penilaian untuk meningkatkan kualitas pembelajaran matematika di sekolah dasar. Paper presented at the Seminar Nasional Matematika, Jakarta.

Lee, C. (2006). Language for learning mathematics: Assessment for learning in practice. Berkshire, England: Open University Press.

Lianghuo, F., \& Mei, Y. S. (2007). Integrating oral presentation into mathematics teaching and learning: An exploratory study with singapore secondary students. The Montana Mathematics Enthusiast, Monograph, 3, 81-98.

Ma, X., Millman, R., \& Wells, M. (2008). Infusing assessment into mathematics content courses for pre-service elementary school teachers. Educational Research for Policy and Practice, 7(3), 165-181. doi: 10.1007/s10671-008-9050-5

McMillan, J. H., \& Hearn, J. (2008). Student self-assessment: The key to stronger student motivation and higher achievement. Educational Horizons, 87, 40-49.

Miller, M. D., Linn, R. L., \& Gronlund, N. E. (2012). Measurement and assessment in teaching: Pearson Higher Ed.

Purnomo, Y. W. (2014). Assessment-Based Learning: Sebuah Tinjauan untuk Meningkatkan Motivasi Belajar dan Pemahaman Matematis. Sigma, VI(1), 22-33.

Purnomo, Y. W. (2015). Pengembangan desain pembelajaran berbasis penilaian dalam pembelajaran matematika. Cakrawala Pendidikan, XXXIV(2), 182-191. 
Redhana, I. W. (2014). Pengaruh model pembelajaran seminar socrates terhadap hasil belajar siswa. Cakrawala Pendidikan, XXXIII(1), 27-38.

Rowe, M. B. (1986). Wait time: slowing down may be a way of speeding up! Journal of teacher education, 37, 43-50. doi: 10.1177/002248718603700110

Rowe, M. B. (1987). Using wait time to stimulate inquiry. In W. W. Wilen (Ed.), Questions, questioning techniques, and effective teaching (pp. 95-106). Washington, DC: NEA Professional Library.

Sadler, D. R. (1989). Formative assessment and the design of instructional systems. Instructional science, 18(2), 119-144.

Webb, N. L. (1992). Assessment of students' knowledge of mathematics: Steps toward a theory. In D. Grouws (Ed.), Handbook of research on mathematics teaching and learning (pp. 661-683). New York: MacMillan.

Wilen, W. W. (1987). Effective questions and questioning: A classroom application. In W. W. Wilen (Ed.), Questions, questioning techniques, and effective teaching (pp. 107-134). Washington, D. C.: National Education Association.

Wiliam, D., Lee, C., Harrison, C., \& Black, P. (2004). Teachers developing assessment for learning: Impact on student achievement. Assessment in Education, 11(1), 49-65. doi: 10.1080/0969594042000208994

Wolf, D., Bixby, J., Glenn III, J., \& Gardner, H. (1991). To use their minds well: Investigating new forms of student assessment. Review of research in education, 31-74. doi: 10.3102/0091732X017001031 